\title{
HOW TO MEASURE INFORMATION AND COMMUNICATION TECHNOLOGY PERFORMANCE: A LITERATURE REVIEW
}

\author{
Ana Gargallo Castel, University of Zaragoza (Spain), gargallo@unizar.es \\ Carmen Galve Gorriz, University of Zaragoza (Spain), cgalve@unizar.es
}

\begin{abstract}
This paper presents a systematic literature review of the impact of information and communication technologies from a firm performance perspective. We introduce and describe a framework of classification according to several economic performance measures. As in previous studies, we distinguish market value and accounting measures, but we also highlight the importance of intermediate measures and other performance measures such as customer satisfaction, effectiveness, quality or turnover ratios to understand the mixed results of past work. These measures have become increasingly important in recent academic studies. The paper presents a broad view of the literature on ICT's impact, and offers suggestions to improve future research.
\end{abstract}

Keywords: Information and Communication Technology, performance, productivity, quality, accounting measures, literature review

\section{INTRODUCTION}

Management researchers have shown increasing interest in the integration and strategic repercussions of information and communication technology (ICT) in the firm since Leavitt and Whisler [42] speculated about the effects of a new technology that they called "information technologies". These technologies continued evolving after this point, and studies on the impact of ICT began to appear in the early 1980s. But exactly what this impact is remains an open question in the specialist literature [20,21,39]. In this line, a topic that has gained a substantial amount of attention in the past few years is how to seize the economic benefits of information and communication technologies ([53]. This has important repercussions at the organizational level, since the difficulty in measuring ICT's impact may discourage firms from investing in these technologies.

In general, the impact of ICT can be measured in many different ways, and although authors have come to some consensus about ICT's positive impact on some variables (e.g., productivity), there is much less agreement about its impact on others (e.g., profitability).

This paper provides an overview of the measures used in the literature and an integrative framework for their classification. Figure 1 shows the theoretical framework that guides this work. ICT is one of the productive inputs to the organizational process or processes, and usually complementary factors are also introduced and will ultimately have an effect, along with ICT, on the outputs of the process. This work aims to offer a framework of reference that organizes and integrates the literature on the benefits of ICT from a global perspective.

$$
\text { <insert Figure } 1 \text { here> }
$$

The next section reviews the concept of business success, and then some of the measures that can be identified as outputs of the process (Figure 1). The following sections review the empirical literature analyzing the relation between ICT and firm performance from various perspectives. The work ends with the conclusions of this analysis, the potential gaps and possible future lines of research.

\section{COMPETITIVE SUCCESS AND ITS DETERMINATION}

The strong interrelations that characterize the current dynamic of organizations make defining the variable performance precisely a highly complex task [17]. For ICT's impact on performance, moreover, it is difficult to isolate the effect of other elements and of the complementarity relations. It is also often impossible to objectively measure some of the most important intangible benefits of ICT use.

Despite this, Aczel [1] argues that the benefits of ICT can be classified in three dimensions: efficiency, which would include reductions in the cost of operations, products and services; effectiveness, delivering more value for investments; and productivity, ensuring that the right things are automated, and measured by the degree of fit between the investments in ICT and the firm's objectives. As later sections show, prominent among these variables is a series of accounting and financial economics indicators commonly used in research on competitiveness and business success, while others take a more flexible approach, using a wide range of measures such as consumer welfare, quality, delivery times, and so on. The diversity of indicators used in the literature has, as the following sections show, occasionally led to contradictory or relatively inconclusive results with regard to the relation between ICT investments and the firm's competitiveness and strategic position. 


\section{PRODUCTIVITY MEASURES}

This perspective considers that inputs can be related to outputs by a production function. An increase in the output requires either an increase in at least one of the inputs, or a change in the technology, or an improvement in management efficiency. A majority of studies choose a Cobb-Douglas production function, where the coefficients can be interpreted directly as the output elasticity of ICT.

Within this framework, one of the most studied topics has been the so-called Productivity Paradox, suggested after the appearance of work failing to find a relation between ICT and productivity, or of some work even finding a negative relation. Among the research examining this question, Brynjolfsson and Hitt's body of work stands out. Brynjolfsson [12] offers various explanations of this paradox, including the difficulty in measuring the productivity of ICT investments, the time-lag in the results, and problems of overinvestment related to agency costs. Loveman [46] offers one of the first econometric analyses in his study of 60 manufacturing firms between 1978 and 1984. This author concludes that increasing investments in ICT capital has no effect on labor productivity, but positive marginal benefits accrue to the rest of the capital. He suggests that this is due to the absence of complementary organizational changes. In contrast, other research finds that marginal productivities for ICT exceed those for the rest of the firm's capital. For example, Lichtenberg [45] and Brynjolfsson and Hitt $[14,15,16]$ find that the marginal benefit associated with ICT investments exceeds the marginal cost, and also the returns to the investments in conventional capital. Similar conclusions are reached by other authors $[6,44$, or 41].

\section{PROFITABILITY MEASURES}

Another approach to analyzing the correlation between ICT and performance is to use some measures of profitability. The empirical evidence is sometimes contradictory in this case, because the relation is less direct than in the case of productivity [26], and because financial results depend not only on the firm's resources but also on a great variety of strategic factors related to the sector to which the firm belongs.

The most common conclusion in studies of profits is that although investments in ICT affect productivity, this does not necessarily increase profits. For example, Hitt and Brynjolfsson [36] fail to find a positive relation between ICT and any of the profitability ratios they use (ROA, ROE and total stockholder profitability). Similarly, Rai et al.
[55] find a positive association between ICT investments and productivity but a much weaker association between ICT and ROA. Similarly, Sircar et al. [61] obtain significant correlations between ICT and various performance indicators related to sales, assets and market value, but not net income. In a more recent study Beccalli [7] also fails to find significant relations between ICT investments and profitability.

Other work introduces the importance of the fit between ICT and company strategy, as well as the development of ICT-related capabilities. Floyd and Wooldridge [32] jointly analyze the relations between strategy, ICT and financial performance, and find that ICT and strategy have a direct effect on performance. They also find indirect effects generated by the fit, or lack of fit, between ICT and strategy, so that if the firm's ICT fits its strategic management, the firm obtains a superior ROA. Bharadwaj [9] and Santhanam and Hartono [59] study the relation between firms with superior ICT capability and various financial indicators. They find a positive relation between the unique capabilities generated by the use of ICT and firm performance measured by various profitability ratios (ROA, ROS, etc.). Using a different sample, Stratopoulos and Dehning [65] compare various measures of financial profitability (ROA, ROE, ROI, etc.) and efficiency (essentially turnover). They find that firms with a competitive advantage deriving from an ICT-enabled strategy perform better. Tallon and Kraemer [67] conclude that in order for the firm's ICT capabilities to improve its performance (ROA, ROS, and the ratio of operating income to assets) they must support the business strategy - what is really important is the strategic fit. Equally, Ravichandran and Lertwongsatien [56] conclude that operational performance (profitability, productivity and financial results) and market performance (success in new market entry and new product launches) depend on the extent to which the resources and capabilities of the ICT support and enhance the firm's core competencies via the capabilities acquired through the ICT human capital and ICT infrastructure flexibility.

On the other hand, Strassmann [63,64] fails to find a correlation between ICT and firm performance measured by traditional rates, such as ROI and ROE. He consider that existing ratios are inadequate and he propose a ratio that fully accounts for the Management Value-Added as well as all of the costs of management as the Return-onManagement index. This ratio is gaining acceptance among company managers as a measure of corporate performance [49] and it is seen as more appropriate than other conventional measures because managers can use it to quantify the organization's overall efficiency in its use of ICT to support knowledge-related tasks. Prattipati and 
Mensah [54] carry out a discriminant analysis of firms with high and low information productivity indexes and they find out differences in performance associated with the firms' ICT investments.

\section{MARKET MEASURES}

The advantage of using measures based on the market is that they can capture intangible elements that ICT investments entail, difficult to measure in other ways $[10,17]$. But they do assume the existence of an efficient market capable of estimating the future benefits of the ICT investments. Bharadwaj and Konsynsky [8] and Richardson et al. [58] conclude that ICT relates positively to Tobin's q, the ratio of the market value of the firm's assets to their replacement costs. Moreover, Brynjolfsson et al. [17] find that the effect on Tobin's q is stronger for firms that make intensive use of certain organizational practices such as the use of skilled workers or team-oriented production, which shows that ICT and new work practices are complementary.

Using event analysis, Dos Santos et al. [30] find increases in the stock price after announcements of ICT investments only when the ICT is "innovative", indicating that the stockholders take into account the innovative nature of the ICT investment. Im et al. [38] extend the sample used by Dos Santos et al. [30], and obtain significant positive increases in firms' market value after announcements of investments in ICT. But when they distinguish between the financial and manufacturing sectors, they find positive returns only in the first case, and when they distinguish between firms of different sizes, only in small firms. This may be because these announcements contain more novel information for investors in the case of small firms. Hayes et al. [35] obtain similar results, finding larger increases in market value after announcements of the adoption of ERP systems in smaller firms and in firms using larger vendors.

Dehning et al. [28] find that Dos Santos et al. and Im et al.'s [30,38] results are no longer significant when ICT strategic role is included as an explanatory variable. They find abnormal increases in the market value when the announcements are of investments in "transformative" ICT, and that these increases are greater for firms belonging to sectors where ICT has more of a transformative role, meaning that firms can use such investment to transform processes, practices and business models and hence improve their competitive position in the sector. Also using the event methodology, Chatterjee et al. [23] find that the increases in the firm's market value after announcements of ICT investments are greater when the investment is in ICT infrastructures than when it is in ICT applications.

Krishnan and Sriram [40] study the effect of investments in ICT associated with the year-2000 effect (Y2K) made in 1997. They find a significant positive relation between this investment and stock prices after controlling for various factors. Recently, Anderson et al. [2] observe increases in market value and revenues in firms that spent more on Y2K, especially in sectors where ICT is thought to be highly influential in transforming the traditional ways of doing business.

Lee et al. [43], studying e-commerce initiatives, find abnormal returns in a sample of listed Korean firms after announcements of e-commerce initiatives, indicating that the market highly values the potential of these initiatives to generate important benefits in the future. Subramani and Walden [66] offer similar results, particularly in business-to-consumer e-commerce. Similarly, Geyskens et al. [33] evaluate the impact of adding a new Internet channel in the newspaper industry. They find that the firm's market value reacts positively to these initiatives on average, while there are positive or negative effects in different newspapers. Their results suggest that powerful firms with a few direct channels achieve greater gains in financial performance than less powerful firms with a broader direct channel offering. Ettredge and Richardson [31] add the effect of risk in e-commerce to the analysis, and find an association between falls in the market value of various Internet firms in the year 2000 and measures of e-risk. In contrast, Hovav and D'Arcy [37] fail to find significant relations between denial-of-service attack announcements and the stock price.

Finally, some authors believe that in order to achieve a competitive advantage other aspects are particularly important, such as ICT-related experience and capabilities, managers' knowledge of ICT, and so on [47]. In this line, Richardson and Zmud [57] find increases in the market value of Internet firms after announcements of new board members with e-commerce experience, showing that stockholders value board members' ability to help the executive team develop innovative strategies on the Internet. Chatterjee et al. [22] also obtain positive abnormal returns after announcements of the creation of a new Chief Information Officer position, particularly in sectors where ICT favors important transformations. 


\section{MEASURES OF INTERMEDIATE RESULTS}

In the literature on ICT's impact in organizations researchers have shown less interest in measures of intermediate results such as level of innovation, improvement in the decision-making, and so on, than in measures such as productivity, profitability, market value, and so on. Thus, Dehning and Richardson [27], discussing the gaps that they find after their literature review, cite this area as one of the possible future lines of research in the ICT area. These authors argue that one of the most important aspects to research is the direct effects of ICT on the outputs of the processes, and in a second step, the effect of these outputs on the final financial performance, since the majority of studies examine the relation between ICT and performance without taking into account the analysis of the process.

In recent years various researchers have examined this question in more detail, some basing their work on theoretical developments such as Davenport [24] or Hammer and Champy [34], who analyze the relation between ICT and final performance through an analysis of the intermediate results.

Thus, Srinivasan et al. [62] find that EDI technology benefited Chrysler's suppliers and customers by making the information about materials more precise and reducing shipment discrepancies, and Mukhopadhyay et al. [51] find that implementing EDI leads to tangible improvements in the performance (cost savings in inventory maintenance, improvements in inventory obsolescence and transport, and so on), as well as, and to a greater extent, in intangible aspects. Likewise, Barua et al. [5] identify a positive relation between ICT and various intermediate processes such as inventory turnover, capacity utilization, quality, new product introduction, as well as between some of these processes and the firm's overall performance, although the effect is generally too weak to affect the final output. Devaraj and Kohli [29] also find evidence that the use of ICT positively affects performance, both financial (revenue per patient and per admission) and non-financial (mortality rate), in a sample of eight hospitals, while Athey and Stern [3] find that using ICT cuts the response time after an emergency call, and in particular reduces the number of deaths from heart problems.

On the other hand, Mitra and Chaya [50] and Shin [60] find that ICT investments are related to lower average total costs. Moreover, Shin [60] analyzes the relation between ICT, intermediate results and the final output, and finds that expenditure on ICT are positively related to the firm's output.
Mukhopadhyay et al. [52] find considerable improvements in the quality of processing mail service as well as in output levels (volume of mail sorted) after improvements in ICT are introduced. Moreover, Byrd [19] argues that ICT allows organizations to improve their core competencies and achieve competitive advantage thanks to the flexibility that the technologies offer. Specifically, the author focuses on explaining the core competencies deriving from improvements in the time-to-market and market orientation. This is coherent with the improvements lead times and ontime delivery percentages observed by McAfee [48].

As Bartel et al. [4] show, ICT reduces setup times, allowing firms to switch production between products at less cost in order to offer more customized products. ICT also reduces the production and inspection times, thereby improving the efficiency of the process as a whole.

\section{CONSUMER WELFARE}

In studies on profits and profitability firms are assumed to retain the value created by their investments in ICT, or at least capture a significant part of it [13]. But firms can sometimes fail to exploit this created value and it is the customers who benefit from the improvements that ICT generates. To determine this aspect, various studies have focused on analyzing consumer welfare, which measures the net value that consumers gain from their purchase of a good, discounting the price they pay for it.

Bresnahan [11] analyzes ICT's effect on the consumer surplus in the financial-services sector and he obtains a significant positive relation between these two variables. Specifically, the advantages that the consumer gains from the computerization of financial services are five times greater than the expenditure on ICT.

In the same way, Hitt and Brynjolfsson [36] use three different approaches to measure ICT's impact on firm output: the production perspective; strategic competitiveness; and consumer welfare. For their empirical analysis they obtain different effects of ICT on each of the variables, with the effect on profits being non-significant while the effect on the other two variables is significant. They also observe that the investments in ICT increase the part of the profits that goes to the customers substantially, and hence improve consumer welfare.

Finally Brynjolfsson [13], in a study focusing exclusively on the consumer surplus, which is estimated using four different measures, finds that ICT investments generate approximately three 
times their cost in consumer value, while Brynjolfsson et al. [18] find that ICT allows firms to offer a greater variety of products to the consumer through electronic markets.

\section{CONCLUSIONS}

ICT's importance and the difficulty in measuring and evaluating its benefits have generated an extensive literature, both quantitative and qualitative. As this work has shown, the studies reviewed shed important light on the effect of ICT on various measures of performance, and offer possible explanations for the discrepancies in many of the findings. In general, authors find that ICT has a positive effect on productivity measures and a negative effect on profitability measures, indicating that ICT usually proves to be a structural necessity for firms to keep up with their competitors. On the other hand, the market measures are interesting because they are able to capture the current and future benefits of the technologies, particularly the intangible benefits, such as increases in the firm's flexibility and improvements in product and process quality, which are not captured directly in the conventional ratios. Market measures also take account of the effects deriving from the existence of complementarities between ICT and the rest of the firm's resources and capabilities.

This last aspect is one of the most interesting to current researchers on the question, since ICT rarely generates results alone [25]. On the contrary, the general view is that in this process researchers need to take into account the effect of complementary elements such as aspects of internal organizational design. ICT's impact on organizational results will be influenced by the synergies of these technologies with the firm's resources and capabilities, so that technological change will only lead to improvements in organizational performance if the organizational processes are managed correctly.

Some authors have included various complementary elements in the study of ICT's impact, but much remains to be learnt about the processes involved in an adequate use of these technologies in order for firms to be able to achieve sustainable competitive advantage and superior performance. Thus, there is a need for future work to carry out a joint analysis of the intermediate business processes and the complementary elements that ultimately influence the value ICT adds to organizations. Contributions in this line should help explain the mixed results of past work highlighted here.

Acknowledgement: The authors would like to express their thanks for the financial support received under the Research Project SEJ200614685 and the "Cátedra de la Empresa Familiar", University of Zaragoza (Spain).

\section{REFERENCES}

1. Aczel, C. (1998). Managing technology investments. CMA Magazine, July/August, 72(6), 15-18.

2. Anderson, M.C., Banker, R.D. \& Ravindran, S. (2006). Value implications of investments in information technology. Management Science, 52 (9), 1359-1376.

3. Athey, S. \& Stern, S. (2002). The impact of information technology on emergency health care outcomes. RAND Journal of Economics, 33 (3), 399-432.

4. Bartel, A., Ichniowski, C. \& Shaw, K. (2007). How does information technology affect productivity? Plant-level comparisons of product innovation, process improvement and worker skills. Forthcoming, Quarterly Journal of Economics

5. Barua, A., Kriebel, H.C. \& Mukhopadhyay, T. (1995). Information technologies and business value: An analytic and empirical investigation. Information Systems Research, 6 (1), 3-23.

6. Barua, A. \& Lee, B. (1997). The information technology productivity paradox revisited: A theoretical and empirical investigation in the manufacturing sector. The International Journal of Flexible Manufacturing Systems, 9(2), 145-166.

7. Beccalli, E. (2005). Does IT investment improve bank performance? Evidence from Europe. Available: http://www.lse.ac.uk/collections/accountingAn dFinance/facultyAndStaff/Beccalli\%20\%20IT.\%20Paper.pdf

8. Bharadwaj, A.S. \& Konsynski, B.R. (1997). Capturing the intangibles, Information Week, Issue 649, 71-74.

9. Bharadwaj, A.S. (2000). A resource-based perspective on information technology capability and firm performance: An empirical investigation. MIS Quarterly, 24(1), 169-197

10. Bharadwaj, A.S., Bharadwaj, S.G.\& Konsynski, B.R. (1999). Information technology effects on firm performance as measured by Tobin's q. Management Science, 45(6), 1008-1025.

11. Bresnahan, T. F. (1986). Measuring the spillovers from technical advance: Mainframe computers in financial services. American Economic Review, 76(4):742-755.

12. Brynjolfsson, E. (1993). The productivity paradox of information technology. Communications of ACM, 36(12), 66-77. 
13. Brynjolfsson, E. (1996). The contribution of information technology to consumer welfare. Information Systems Research 7(3), 281-300.

14. Brynjolfsson, E. \& Hitt, L. (1995). Information technology as a factor of production: The role of differences among firms. Economics of Innovation and New Technology (Special Issue on Information Technology and Productivity Paradox), 3 (4), 183-200.

15. Brynjolfsson, E. \& Hitt, L. (1996). Paradox lost? Firm-level evidence on the returns to information systems spending. Management Science, 42(4), 541-558.

16. Brynjolfsson, E. \& Hitt, L. (2003). Computing productivity: Firm-level evidence. Review of Economics and Statistics, 85(4), 793-808.

17. Brynjolfsson, E., Hitt, L. \& Yang, S. (2002). Intangible assets: Computers and organizational capital. Brookings Papers on Economic Activity, 1, 137-98.

18. Brynjolfsson, E., Smith, M.D. \& Hu, Y. (2003). Consumer surplus in the Digital Economy: Estimating the value of increased product variety at online booksellers. MIT Sloan School of Management, Working Paper 4305-03.

19. Byrd, T.A. (2001). Information technology: Core competencies and sustained competitive advantage. Information Resources Management Journal, 14(2), 27-36.

20. Byrd, T.A. and Davidson, N.W. (2006). An empirical examination of a process-oriented IT business success model. Information Technology and Management, 7(2), 55-69.

21. Byrd, T.A., Thrasher, E.H., Lang, T. \& Davidson, N.W. (2006). A process-oriented perspective of IS success: Examining the impact of IS on operational cost. Omega, 34(5), 448-460.

22. Chatterjee, D., Richardson, V.J. \& Zmud, R.W. (2001). Examining the shareholder wealth effects of new CIO position announcements. MIS Quarterly, 25 (1), 43-70.

23. Chatterjee, D., Pacini, C. \& Sambamurthy, V. (2002). The shareholder-wealth and tradingvolume effects of information-technology infrastructure investments. Journal of Management Information Systems, 19(2), 7-42.

24. Davenport, T.H. (1993). Process innovation: Reengineering work through information technology. Boston, Harvard Business School Press.

25. Davern, M.J. \& Kauffman, R.J. (2000). Discovering potential and realizing value from information technology investments. Journal of Management Information Systems, 16(4), 121143.

26. Dedrick, J., Gurbaxani, V. \& Kraemer, K.L. (2003). Information technology and economic performance: A critical review of the empirical evidence. ACM Computing Surveys, 35(1), 128.

27. Dehning, B. and Richardson, V.J. (2002). Returns on investments in information technology: A research synthesis. Journal of Information Systems, 16(1), 7-30.

28. Dehning, B., Richardson, V.J. \& Zmud, R.W. (2003). The value relevance of announcements of transformational information technology investments. MIS Quarterly, 27 (4), 637- 656.

29. Devaraj, S. \& Kohli, R. (2003). Performance impacts of information technology: Is actual usage the missing link?. Management Science, 49 (3), 273-289.

30. Dos Santos, B.L., Peffers, G.K. \& Mauer, D.C. (1993). The impact of information technology investment announcements on the market value of the firm. Information System Research, 4 (1), 1-23

31. Ettredge, M. \& Richardson, V. J. (2002). Assessing the risk in e-commerce. Proceedings of the 35th Hawaii International Conference on System Sciences (HICSS-35 2002).

32. Floyd, S.W. \& Wooldridge, B. (1990). Path analysis of the relationship between competitive strategy, IT, and financial performance. Journal of Information Systems, 7(1), 47-64.

33. Geyskens, I., Gielens, K. \& Dekimpe, M.G. (2002). The market valuation of Internet channel additions. Journal of Marketing, 66 (2), 102-119.

34. Hammer, M. \& Champy, J. (1993). Reengineering the corporation: A manifesto for business revolution. New York, NY: McGrawHill.

35. Hayes, D.C., Hunton, J.E. \& Reck, J.L. (2001). Market reaction to ERP implementation announcements. Journal of Information Systems, 15 (1), 3-18.

36. Hitt, L. M., Brynjolfsson, E. (1996). Productivity, business profitability and consumer surplus: Three measures of information technology Value. MIS Quarterly, 20(2), 121-142.

37. Hovav, A. \& D’Arcy, J. (2003). The impact of denial-of-service attack announcements on the market value of firms. Risk Management and Insurance Review, 6(2), 97-121.

38. Im, K.S., Dow, D.E. \& Grover, V. (2001): A Reexamination of IT Investment and the Market Value of the Firm. An Event Study Methodology. Information Systems Research, 12 (1), 103-117.

39. Kafouros, M.I. (2006). The impact of the Internet on R\&D efficiency: theory and evidence. Technovation, 26 (), 827-835.

40. Krishnan, G.V. \& Sriram, R.S. (2000). An examination of the effect of IT investments on firm value: The case of Y2K-compliance costs. 
Journal of Information Systems, 14 (2), 95109.

41. Kudyba, S. \& Diwan, R. (2002). Research Report: Increasing Returns to Information Technology. Information Systems Research, 13 (1), 104-111.

42. Leavitt, H.J. \& Whisler, T.L. (1958). Management in the 1980's. Harvard Business Review, 41-48.

43. Lee, H.G., Cho, D.H. \& Lee, S.C. (2002). Impact of e-business initiatives on firm value. Electronic Commerce Research and Application, 1(1), 41-56.

44. Lehr, W. \& Lichtenberg, F. (1999). Information technology and its impact on productivity: firm-lvel evidence from government and private data sources, 19771993. Canadian Journal of Economics, 32(2), 335-362.

45. Lichtenberg, F. (1995). The output contribution of computer equipment and personnel: A firm level analysis. Journal of Economics of Innovation and New Technology, 3 (), 201-217.

46. Loveman, W. (1994). An assessment of productivity impact on information technologies. In: Allen, T. \& Scott Morton, M.S. (ed.). Information technology and the corporation of the 1990's: Research Studies. New York, NY: Oxford University Press, pp. 84-110.

47. Mata, F., Fuerst, W.L. \& Barney, J.B., (1995). Information technology and sustained competitive advantage: A resource-based analysis. MIS Quarterly, 19(4), 487-505.

48. Mcafee, A. (2002). The impact of entreprise information technology adoption on operational performance: An empirical investigation. Production and Operations Management, 11(1), 33-53.

49. Mills, R. \& Print, C. (1995). Uses of shareholder value analysis and economic value added. Management Accounting (British), 73(2), 35-38.

50. Mitra, S. \& Chaya, A.K. (1996). Analyzing cost-effectiveness of organizations: The impact of technology spending. Journal of Management Information Systems, 13(2), 2957.

51. Mukhopadhyay, T., Kekre, S. \& Kalathur, S. (1995). Business value of information technology: A study of Electronic Data Interchange. MIS Quarterly, 19(2), 137-156.

52. Mukhopadhyay, T., Rajiv, S. \& Srinivasan, K. (1997). Information technology impact on process output and quality. Management Science, 43(12), 1645-59.

53. OECD (2004). The economic impact of ICT measurement, evidence and implications. Available: http://www1.oecd.org/publications/ebook/9204051E.PDF

54. Prattipati, S.N. \& Mensah, M.O. (1997). Information systems variables and management productivity. Information and Management, 33(1),33-43. 33:11.

55. Rai, A., Patnayakuni, R. \& Patnayakuni, N. (1997). Technology investment and business performance. Communications of the ACM, 40(7), 89-97.

56. Ravichandran, T. \& Lertwongsatien, C. (2005). Effect of information systems resources and capabilities on firm performance: A ResourceBased Perspective. Journal of Management Information Systems, 21(4), 237-276.

57. Richardson, V. J., \& Zmud, R. W. (2001). Wealth effects accompanying appointments of outside directors to the boards of Internet companies. Working paper, University of Kansas.

58. Richardson, V.J., Subramani, M. \& Zmud, R.W. (2003). Benefiting from information technology investments: The role of IT conversion capability. Mimeo 2003.

59. Santhanam, R. \& Hartono, E. (2003). Issue in linking information technology capability to firm performance. MIS Quarterly, 27(1), 125153.

60. Shin, N. (2003). An empirical Analysis of Productivity Gains from Information Technology's Reduction of Coordination Costs. In Shin, N. (ed.). Creating business value with information technology: Challenges and solutions, Hershey, Pennsylvania: Idea Group Publishing, pp. 1-22.

61. Sircar, S., Turnbow, J.L. \& Bordoloi, B. (2000). A framework for assessing the relationship between information technology investments and firm performance. Journal of Management Informations Systems, 16(4), 6997.

62. Srinivasan, K., Kekre, S. \& Mukhopadhyay, T. (1994). Impact of Electronic Data Interchange technology on JIT shipments. Management Science, 40(10), 1291-1304.

63. Strassmann, P.A. (1990). The business value of computers: An executive guide. New Canaan: Information Economics Press.

64. Strassmann, P.A. (1997). Will big spending on computers guarantee profitability?. Datamation, 75-85.

65. Stratopoulos, T. \& Dehning, B. (2000). Does successful investment in information technology solve the productivity paradox? Information \& Management 38(2), 103-117.

66. Subramani, M., \& Walden, E. (2001). The impact of e-commerce announcements on the market value of the firm. Information Systems Research, 12 (2), 135-154. 
67. Tallon, P. \& Kraemer, K. (2005). The impact of IT capabilities on firm performance: Perspectives on the mediating effects of strategic alignment. Available: http://www.crito.uci.edu/2/iab/0502/tallon.pdf

\section{TABLES AND FIGURES}

Figure 1. Theoretical framework at firm level

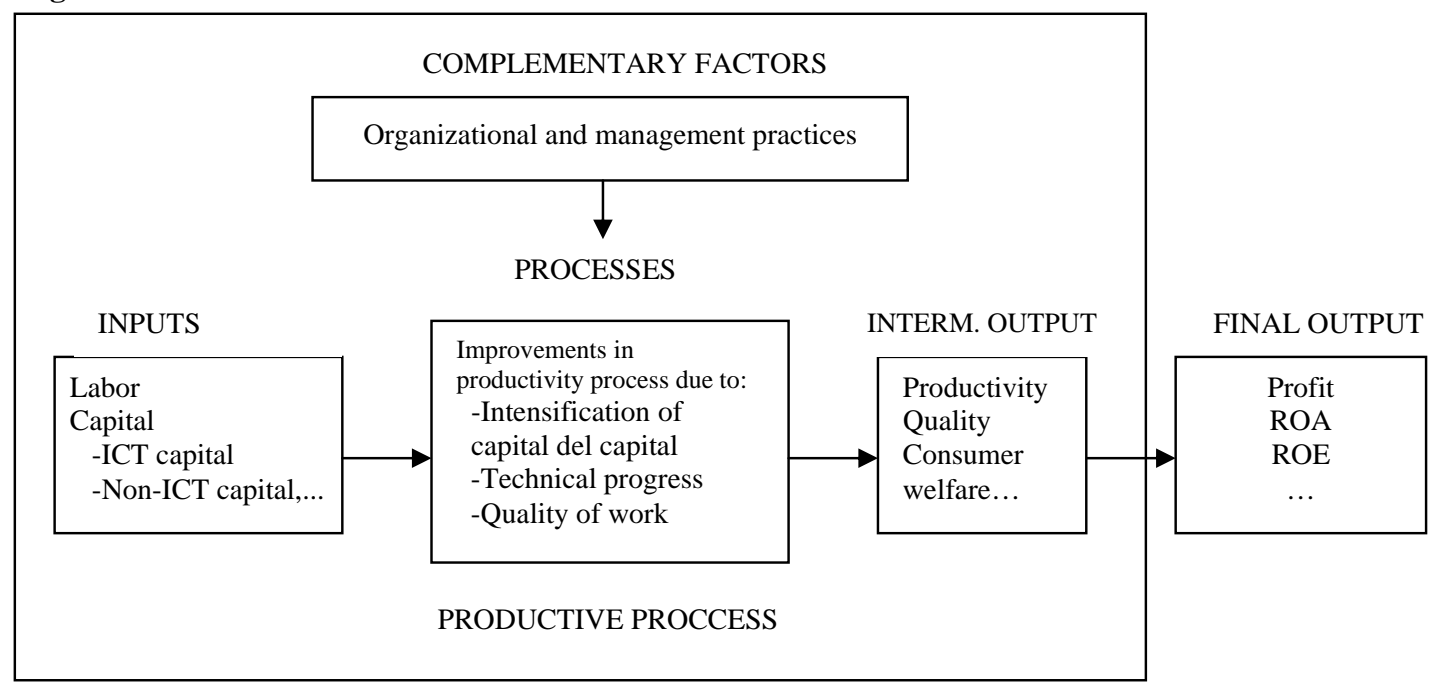

Source: Adapted from Dedrick et al. [26] 